\title{
Design Framework as a Prototype of Islamic Medicine Engine to any Disease Especially for Covid-19 Based Al-Qur'an and Hadith Using Meta-Deep AI and Particle Swarm Optimization
}

\author{
Imam Cholissodin ${ }^{1, *}$, Arief Andy Soebroto ${ }^{2}$, Mohammad Muallif ${ }^{3}$, \\ Aurick Yudha Nagara ${ }^{4}$, Renny Nova ${ }^{5}$, Tamara Gusti Ebtavanny ${ }^{6}$ \\ ${ }^{1,2}$ Faculty of Computer Science, Computer Science, Universitas Brawijaya, Malang, Indonesia \\ ${ }^{3}$ Faculty of Economics and Business, Universitas Brawijaya, Malang, Indonesia \\ ${ }^{4,5,6}$ Faculty of Medicine, Universitas Brawijaya, Malang, Indonesia \\ *Corresponding author.Email: imamcs@ub.ac.id
}

\begin{abstract}
In the Islamic world, as a part of the faith, every Muslim must believe that every time there is a disease, Allah SWT has also sent down the medicine. The current issue is that the extraction of information related to diseases and drugs from the Qur'an and Hadith has not been optimal, given the increasing number of diseases that have complexities of symptoms that require long and in-depth investigation if done manually. In addition, there are also some dangerous diseases for humans the cure of which is unknown, one of which is Covid-19. This study proposes an automatic search approach in the form of design framework as Islamic Medicine Engine using Meta-Deep Artificial Intelligence (AI) technology based on optimization techniques that have reliable capabilities in the search process for solutions so that no matter how difficult the search space is, it will still be easy to find the optimal solution. The optimization technique uses the particle swarm optimization (PSO) algorithm which is very fast to identify the solution point being searched, one of the reasons of which is because it contains a meta-heuristic technique. The way this method works is to find the optimal fitness measurement performance value of each particle candidate or as a forerunner to an optimal solution according to constraints/obstacles or parameters of disease symptom features that are included in the testing process for any disease or it is general, especially for Covid-19. From the experimental results, it was discovered that the PSO algorithm could provide convergent recommendations, meaning that it has met the entry criteria for optimum and dynamic global conditions in the form of many alternative solutions offered as candidates for herbal medicine, or at least as a supplement to cure any disease, especially Covid-19, with the permission of Allah SWT.
\end{abstract}

Keywords: Design, Framework, Prototype, Islamic Medicine Engine, Any Disease, Covid-19, Al-Qur'an and Hadith, Meta-Deep AI, Particle Swarm Optimization

\section{INTRODUCTION}

As the servant of Allah SWT, we are obliged to always obey the whole commands and prohibitions from Allah SWT, with an attitude of patience, sincerity and istiqomah (steadfastness) which Inshallah (if Allah wills) will further increase the level of our faith and devotion to Allah SWT. For Muslims, Allah SWT has guided human life, the form of which includes Al-Qur'an and Hadith through our Prophet Muhammad SAW (PBUH), unquestionably, with strong conviction that every problem that exists must have a solution in the two books.

In life today, Muslims are given a test by Allah SWT in the form of Covid-19, which according to world health experts, the cure as a solution of which is still unknown. Therefore, in several previous research studies, many have revealed that Islamic medicine is highly recommended as an approach and a candidate solution. Among the previous studies, one was carried out by Zaid [1] which employed a historical study between Greco- 
Arab and Islamic Herbal Medicine for cancer, which stated that herbal plants have great potential as a safe alternative medicine for several diseases including cancer, in accordance with several studies that have been carried out in vivo and in vitro to evaluate the efficacy of herbal plants in the treatment of carcinogenesis [1]. Moreover, there was another research about the creation of a search engine on the encyclopedia book of herbal medicine [2] and a research the specification of which mentioned a certain disease, i.e. diabetes mellitus, which can be cured by using more herbs if a complication of diabetes takes place [3]. In addition, there was also a study the focus of which only discussed the review of relevant studies on a variety of foods recommended by Prophet Muhammad (PBUH) and their relationship with the solution treatment of various diseases, which become a huge benefit to the world of health until the present and future [4]. Then, there was an almost similar study, but more concerned with studies related to the truth of hadith of Prophet Muhammad (PBUH) on several herbs, which are connected with science and technology in the field of modern medicine at the time [5].

Some of these studies still have not attempted to develop the outcome using an automation approach in a computerized way using Meta-Deep Artificial Intelligence $(\mathrm{AI})$ by utilizing meta-heuristic-based careful searching techniques with the Particle Swarm Optimization (PSO) algorithm. Once this algorithm is implemented, issues related to the search for drug candidates for all kinds of diseases, especially for Covid19 , in the form of herbs extracted from the information sourced from the Al-Qur'an and Hadith will be very easy to solve and easy to find the reliable, fast, and accurate solutions according to the level of performance measurement values obtained from the results of the algorithm performance value or the fitness value. The result comes in the form of many herbal candidate recommendations for disease solutions in accordance with those entered by the system users whether they are general people in need, the medical community, or patients. This will definitely provide great benefits and become a leap forward on the scientific truths of Islam from Allah SWT which is conveyed through the Prophet Muhammad SAW (PBUH). Furthermore, it shows that Islam is the solution for mankind of all ages, or Rahmatan Lilalamiin.

\section{METHOD}

\subsection{Islamic Medicine from Qur'an \& Hadith}

Descriptions of various kinds of medicine to cure diseases have been very much explained in the Qur'an and Hadith on Fig. 1. It is certainly an obligatory attitude of a Muslim to believe in the truth of those descriptions.
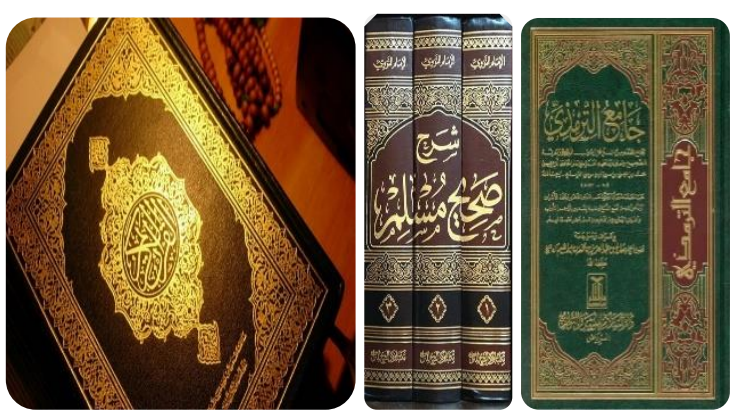

Figure 1 Cover Qur'an and Hadist [6][7][8]

The things that underlie the study of drugs from these two sources are mainly from both sources, also from the increasing number of diseases and from the increasing development of existing technology. The following are some of the hadiths that underlie this study.

\subsubsection{The Word of Allah SWT about several natural remedies in the Qur'an}

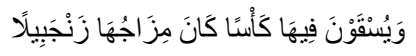

Meaning: "In heaven they will be given a glass (of drink) the mixture of which is ginger." (Surah Al-Insan: 17).

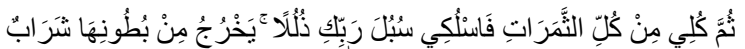

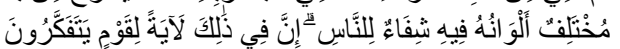

Meaning: "Then eat from every (kind) of fruit and follow the easy ways of your Lord which have been laid (for you). From the stomach of the bee comes forth a drink (honey) of many colors, in which there is healing medicine for humans. In fact, in that there really is a sign (the greatness of God) for people who reflect." (Surah An-Nahl: 69).

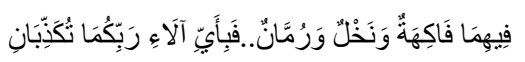

Meaning: "In both there are (various) fruits and dates and pomegranates. Which then of the bounties of your Lord will you deny?" (Surah Ar Rahman 68-69).

\subsubsection{Hadith about a cure for every disease}

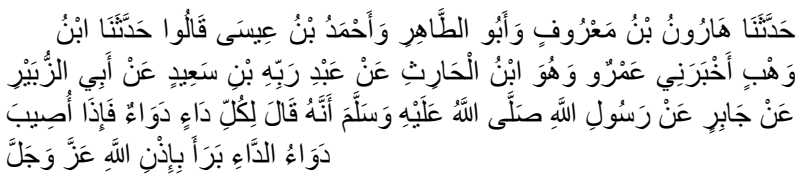

Meaning: "Every disease has a cure. If the right medicine is found for a disease, the disease will be cured with the permission of Allah 'azza wa Jalla." (Muslim). Source: (Ali bin Sulthan bin Muhammad, Marqatul Mafatih, juz 8 p. 345) \& (Imam Muslim, Salam hadith book likulli daain dawaa' chapter no. 4201). 


\subsubsection{Medication advice when sick}

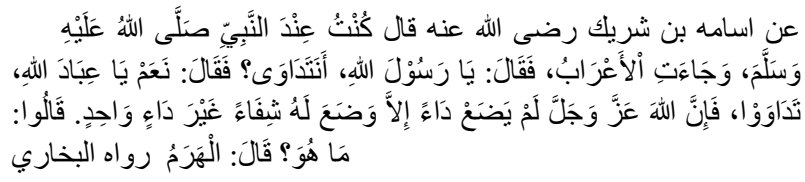

Meaning: I was beside Rasulullah Sallallahu 'alaihi wa sallam. Then came a group of desert Arabs. They asked, "Messenger of Allah, should we make use of medical treatment?" He replied, "Yes, make use of medical treatment for Allah Subhanahu wa Ta'ala has not made a disease without appointing a remedy for it, with the exception of one disease." They asked, "What disease is it?" He said: "Old age." (HR Bukhari). Source: Imam Bukhori, Shohih Bukhori Book of Thib chapter Rajul wa Tadawa juz 4 p. 176.

\subsubsection{Hadith for Immunity and Flu}

يروى عن تميم الدارى انه اهدى النبي صل ل زبيبافلما وضعام بين يديه قال

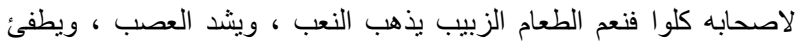
الغضب ، يذهب البلغم ويصفي اللون ، ويطيب النيب النكهة

Meaning: It was told from Tamim ad-darii that one day Tamim gave a gift of raisins to the Prophet Muhammad. When the raisins were in the hands of the Prophet, the Prophet said to his Companions, "Eat raisins because raisins are the best of food; it can relieve fatigue, tighten nerves, relieve emotions, remove phlegm (flu), brighten the skin, and add a delicious aroma for food." Source: (Ibnul Qoyimm Al-Jauzi, Zadul Maad chapter Thibun Nabi juz 3 p. 293).

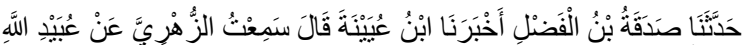

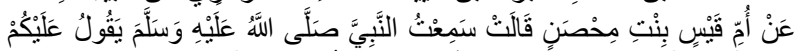

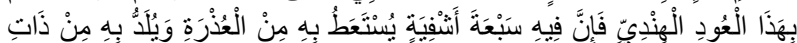

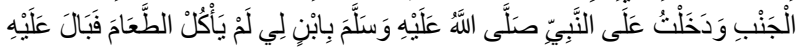

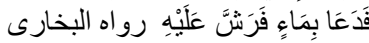

Meaning: "Sadaqah bin Al-Fadl informed us that Ibn 'Uyainah said: I heard Az Zuhri from 'Ubaidullah from Umm Qais bint Mihshan said: I heard the Prophet Muhammad said: "Use the branch of Indian agarwood because inside there are 7 kinds of healers and it can eliminate disease (poison), one among which is inflammation of the lung disease." Source: (Syarah Shohih Bukhari Kitab: Treatment Chapter: Assa'uth with qusthul hindi and qusthul bahri No. Hadith: 5368 juz 10 p. 156).

In the Hadith number 5368 juz 10 p. 156, it mentions the phrase " 7 kinds of healers" which is attempted to be understood by some scholars. It also states that it is related to seven ways of treating a disease, among which are begun to be inhaled, spread, drunk, crushed and then affixed to the sick body, squeezed, evaporated, and put in the mouth. The method of treating diseases by inhaling the aroma of Indian agarwood is the best way of treatment according to the Hadith of the Prophet Muhammad SAW (PBUH) narrated by At Tirmidzi.

\subsection{Proposal: Design Framework as a Prototype of Islamic Medicine Engine Using meta-Deep AI based Particle Swarm Optimization}

\subsubsection{Loading Dataset}

Create a dataset which consists of columns of numbers, all herbal name, and all names of symptoms or diseases that can be cured with the herbs by taking a complete testimony of Qur'an and hadith.

\subsubsection{Setting Input Menu}

Input menu is utilized for the users to enter symptoms of a disease which is used as a test. then, the system is going to load it or perform a reading of the input data. The process of reading the input data will be carried out by prioritizing word expansion techniques that come from synonyms or equivalents of the original word.

\subsubsection{Running Optimization using PSO}

Set PSO parameter value, and then PSO is ready to provide generated solutions as many as the size of the population [9], in which the representation of the solutions emerges in the form of one row and many columns along the column of "amount of herbal medicine" in the form of binary values of $0 / 1$, where 0 means that the herb is not selected and 1 means that the herb is selected. The technique for calculating the fitness value is shown in Equation (1).

$$
\text { Fitness }=\sum_{i=1}^{n \text { Herb }} \text { Match }_{i}
$$

\section{RESULT AND DISCUSSION}

The result of this study was in the form of a draft of diagram design for Islamic Medicine Engine, table scheme for dataset, PSO particle representation. Furthermore, the enhancement came in the form of a test draft design that can be carried out, for example, using three testing scenarios, where each testing utilized common symptom features identified from several sources. The purpose of some of the test design was to determine how good the quality of solutions obtained from each time the program was run. The best result obtained from the test results will be evaluated in regards to the results of the recommendations for herbal medicine candidates generated by the system through the application of the Particle Swarm Optimization (PSO) algorithm. The following is a detail of the design result as the Design Framework as Prototype of Islamic Medicine Engine Using meta-Deep AI based Particle Swarm Optimization. 


\subsection{Diagram of Islamic Medicine Engine}

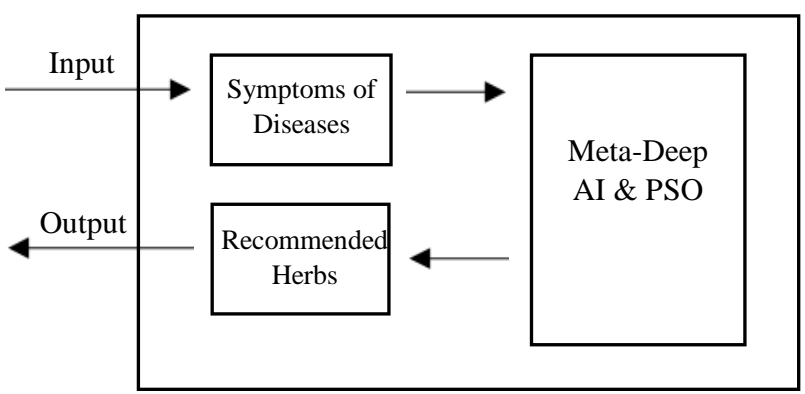

Figure 2 Block Diagram of Islamic Medicine Engine

The illustration of the way prototype of Islamic Medicine Engine Using Meta-Deep AI based Particle Swarm Optimization works can be observed in Fig. 2. Here, it was assumed that the entered disease symptoms were the final examination result. After that, the results generated by Meta-Deep AI based PSO came in the form of one particle, which will provide a recommendation of

Table 1. Scheme of Tables for Dataset

\begin{tabular}{|c|c|c|}
\hline No & Herbs & $\begin{array}{l}\text { Symptoms or Diseases to be } \\
\text { Treatment }\end{array}$ \\
\hline 1 & $\begin{array}{l}\text { Black } \\
\text { Cumin }\end{array}$ & .. \\
\hline 2 & Honey & .. \\
\hline 3 & $\begin{array}{l}\text { Eucalyptus } \\
\text { oil }\end{array}$ & .. \\
\hline 4 & $\begin{array}{l}\text { Indian } \\
\text { Wood } \\
\text { Branches }\end{array}$ & $\begin{array}{l}\text { Disorders of the respiratory } \\
\text { system, throat problems, } \\
\text { pneumonia, decongestants, } \\
\text { scars, burns, insomnia, } \\
\text { constipation, kidney } \\
\text { problems, blood sugar } \\
\text { control, stress, asthma, } \\
\text { chronic gastritis, liver, } \\
\text { stomach ulcers, colitis, } \\
\text { rheumatism, tumor, cancer / } \\
\text { stopping the spread of cancer, } \\
\text { anti-hangover drugs, nausea } \\
\text { and vomiting, fever, malaria, } \\
\text { paralysis, rheumatism, } \\
\text { stomachache, tumors, boils, } \\
\text { vomiting, dysentery, fever, } \\
\text { skin and digestive problems, } \\
\text { arthritis (inflammation of } \\
\text { joints), cholesterol, heart,.. }\end{array}$ \\
\hline 5 & Raisins & \\
\hline .. & .. &.. \\
\hline$m$ & .. & .. \\
\hline
\end{tabular}

one or more relevant herbs according to the symptoms that have been entered by the user.

\subsection{Scheme of Tables for Dataset}

Table 1 is the result of the design as a schematic design of the table for creating a dataset the contents of which were taken from the names of herbs and their benefits from the Qur'an and Hadith and combined with several other sources from articles from previous research, in which $\mathrm{m}$ refers to the number of types of herbs that exist.

Detailed of the complete source code and a recap of Table 1 can be viewed from the link of https://github.com/imamcs19/Islamic-Medicine-Engineto-any-Disease-and-Covid-19-based-Quran-and-Hadithusing-meta-Deep-Ai-PSO and in this study, we carried out a collection in gradual, detailed, and structured stages with the hope that the presentation of the dataset is easy to understand and easy to read by the system in the implementation of the program code.

\subsection{Representation of PSO Particle}

Table 2 shows that the representation of PSO particles in the population is as many as the pop_size.

\subsection{Scheme for testing Covid-19, non-Covid- 19, and Comorbid diseases}

This testing scheme was designed to obtain a combination in a form presented in Table 1, which contains several candidates of drug recommendations that are high in number and very varied from one herb or a combination of several herbs. In this case, the result was not the final drug because if it is final, then it must have been through a clinical trial. Instead, it served only as a recommendation for additional supplements or the prevention and early treatment for Covid-19 patients and for patients with comorbid, or for patients for any disease. Specific for Covid-19, most of the symptoms including respiratory system disorders, throat problems, pneumonia and fever, turned out to be more of a recommendation for treatment using Indian Wood Branches.

Table 2. Initial Position of PSO

\begin{tabular}{|l|l|l|l|l|}
\hline & Herb1 & Herb2 & .. & Herbm \\
\hline $\mathbf{X}_{1}$ & $0 / 1$ & $0 / 1$ & $0 / 1$ & $0 / 1$ \\
\hline $\mathbf{X}_{2}$ & $0 / 1$ & $0 / 1$ & $0 / 1$ & $0 / 1$ \\
\hline$\cdot$. &.. &.. &.. &.. \\
\hline Xpop_size & $0 / 1$ & $0 / 1$ & $0 / 1$ & $0 / 1$ \\
\hline
\end{tabular}




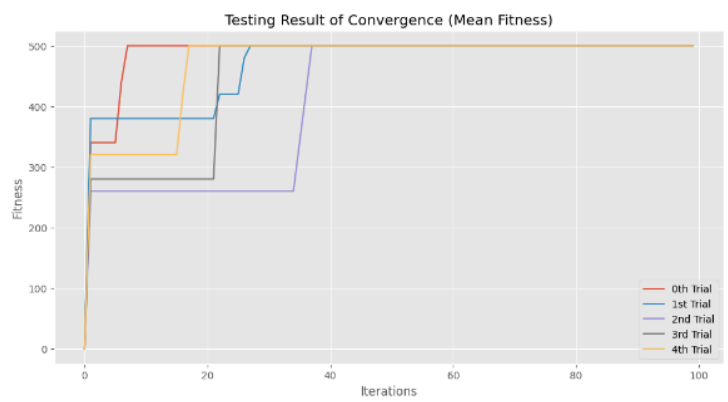

Figure 3 Results of the system convergence graph in the $1^{\text {st }}$ test

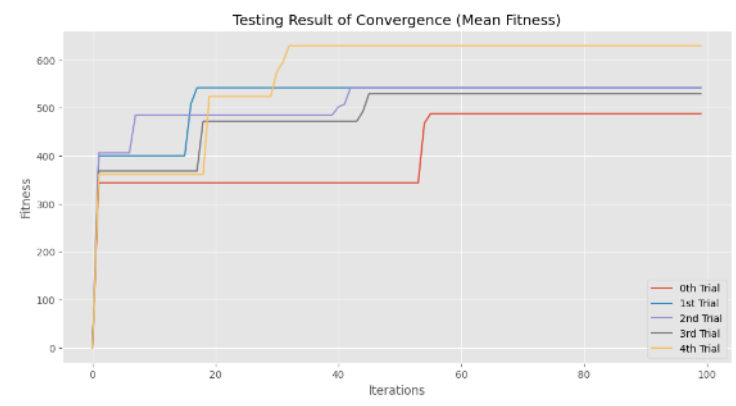

Figure 4 Results of the system convergence graph in the $2^{\text {nd }}$ test

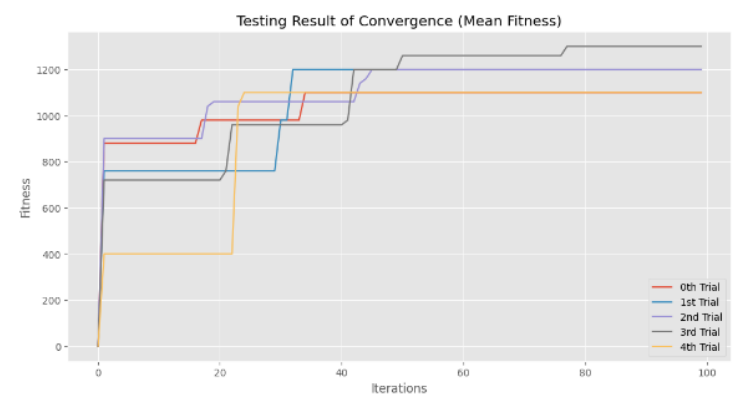

Figure 5 Results of the system convergence graph in the $3^{\text {rd }}$ test

Then, the results for the search simulation utilized the symptom input provided by the user. From several different symptoms, the results showed a convergence graph as in Figure $3-5$, on the recommendation in the form of herbs generated by the system.

\section{CONCLUSION}

Muslim who has straight and true faith and piety will be very confident that what is produced in the draft recommendation, if it has been implemented, Inshallah, contains the truth and evidence. The reason is that indeed the sources taken are the Qur'an and Hadith the truth of which is absolute or essential. If there are other limitations, then it could be in the form of an inaccurate selection of the method used as the foundation of the technology or indeed from the patient concerned that there is another will from Allah SWT. It is suggested that the future research can test it directly in Smart App by providing weight $(w)$ variable at every obtained herb multiplied by the value of Match $_{i}$ variable in the fitness formula as a knowledge base for priority for, as an instance, the manufacture of herbal mixture composition, then added smart feature for consultation with a doctor/pharmacist, and give recommendation how to cook herbs with getting the optimal result. Also, the implementation should be attempted from making comparisons using various optimization algorithms to doing a study in the form of implementation that is mainly directed to discuss the emphasis on the pharmaceutical world Islam further, which leads to the laboratory test results of animal experiments (in vitro) and clinically in the field to patients (in vivo) so that it does not stop on computer simulations (in silico) only.

\section{REFERENCES}

[1] H. Zaid, A. Rayan, O. Said, B. Saad, Cancer Treatment by Greco-Arab and Islamic Herbal Medicine, The Open Nutraceuticals Journal, 3, 2010, pp. 203-212.

DOI: http://dx.doi.org/10.2174/18763960010030100203.

[2] F. Ihsan, A. Syauqi, F. Fatchurrochman, Mesin Pencari Berbasis Semantic Web Menggunakan Algoritma Boyer-Moore Pada Ensiklopedia Tanaman Obat, Fakultas Sains dan Teknologi UIN Maulana Malik Ibrahim Malang, 2013.

[3] B. Moradi, S. Abbaszadeh, S. Shahsavari, M. Alizadeh, and F. Beyranvand, The most useful medicinal herbs to treat diabetes, Biomedical Research and Therapy, vol. 5, no. 8, 2018, pp. 25382551.

[4] S. A. Ali, N. Parveen, \& A. S. Ali, Links between the Prophet Muhammad (PBUH) recommended foods and disease management: A review in the light of modern superfoods, International journal of health sciences, vol. 12, no. 2, 2018, pp. 61-69.

[5] I. Safarsyah, N. Parveen, \& A. S. Ali, Hadits Nabi SAW Tentang Obat Dalam Tinjauan Ilmu Kedokteran Modern, Jurnal Studi Ilmu Al-Qur'an Dan Al-Hadits, vol. 12, no. 2, 2018, pp. 165-188

[6] A. Kurniawan, Ini Hadits Rasulullah Seputar Wabah Penyakit, Thaun, atau Covid-19, 2020, Available At: https://islam.nu.or.id/post/read/118402/ini-haditsrasulullah-seputar-wabah-penyakit--thaun--ataucovid-19

[7] N. Hosen, Jargon 'Kembali kepada al-Qur'an dan Hadis, 2016, Available At: https://www.pcinuanz.org/jargon-kembali-kepada-al-quran-dan-hadis.

[8] Laduni.id, Riwayat Imam At-Tirmidzi, 2018, Available At: 
https://www.laduni.id/post/read/44933/riwayatimam-at-tirmidzi.

[9] I., Cholissodin, E.,Riyandani, Swarm Intelligence, Fakultas Ilmu Komputer, Universitas Brawijaya, Malang. 2016.
[10] (The Qur'an, Al-Insan: 17), with Al-Insan being the chapter and 17 being the verse.

[11] (The Qur'an, An-Nahl: 69), with An-Nahl being the chapter and 69 being the verse.

[12](The Qur'an, Ar Rahman: 69), with An-Nahl being the chapter and 68-69 being the verse. 